\title{
ASIAN ARIDITY AND THE ZONAL WESTERLIES: LATE PLEISTOCENE AND HOLOCENE RECORD OF EOLIAN DEPOSITION IN THE NORTHWEST PACIFIC OCEAN
}

\author{
DAVID K. REA ${ }^{1}$ and MARGARET LEINEN ${ }^{2}$ \\ ${ }^{1}$ Department of Geological Sciences, University of Michigan, Ann Arbor, MI 48109-1063 (U.S.A.) \\ ${ }^{2}$ Graduate School of Oceanography, University of Rhode Island, Narragansett, RI 02882-1197 (U.S.A.)
}

(Received March 25, 1987; revised and accepted December 9, 1987)

\begin{abstract}
Rea, D. K. and Leinen, M., 1988. Asian aridity and the zonal westerlies: Late Pleistocene and Holocene record of eolian deposition in the northwest Pacific Ocean. Palaeogeogr., Palaeoclimatol., Palaeoecol., 66: 1-8.

A 30,000-year record of eolian deposition in the northwestern Pacific Ocean provides a history of the aridity of the Asian source region and information on the changing latitude and intensity of the zonal westerlies. The position of the maximum in eolian flux to the deep sea remained unchanged at $38^{\circ}$ to $40^{\circ} \mathrm{N}$ during this entire time period, but the dust flux record of aridity is greatest 6000 years ago at the Holocene climatic optimum. Eolian grainsize data indicate that the northern margin of the westerly jet stream retreated northward during the Holocene to a poleward extreme at about 6000 years ago and then moved back toward the equator. The change in wind intensity across this margin was continually reduced throughout the Holocene. These sorts of data enhance our understanding of the behavior of the atmosphere during times of climate change and can be used to test computer-generated models of past climatic conditions.
\end{abstract}

\section{Introduction}

The inorganic component of deep-sea sediments, largely minerals derived from the continents, often contains a reliable record of ocean and climate history. About $95 \%$ of the terrigenous material in the ocean arrives by river and is deposited on continental shelves and slopes, for a few hundred kilometers seaward as hemipelagic mud, and occasionally much farther as turbidites. In subpolar regions, floating ice carries grains of all sizes towards the equator, providing clear physical evidence of present and past glacial climates. Seaward of the roughly $500 \mathrm{~km}$ broad zone of hemipelagic deposition and equatorward of the realm of ice rafting, the terrigenous component of pelagic sediment is dominated by wind- blown dust, lifted from dry regions of the continents and transported many thousands of kilometers in the upper troposphere. The mass accumulation rates (MAR) of all these materials record some aspect of their supply to the ocean, and their grainsize distributions, in the absence of abyssal perturbations, should reveal the intensity and variability of their transport. During the past few years we have applied this concept to the eolian component of deep-sea sediments, interpreting from that record both source area aridity and the changing intensity of the transporting winds (Rea et al., 1985).

The study of paleoclimatology has now progressed to the point where important advances can be derived from numerical models of past climates and, most notably, verification 
(or rejection) of such model output by paleoclimatic proxy data. Models of late glacial and Holocene climates have been constructed by the COHMAP (Cooperative Holocene Mapping Project) project members and tested against both continental and marine paleoclimate records (Kutzbach and Guetter, 1986; Prell and Kutzbach, 1987). One feature of these and other climate hindcasts is a time of enhanced climate warming in the early to mid Holocene, 9000 to 6000 years ago, which has long been recognized in proxy climate data. The results of the Kutzbach and Guetter (1986) work with the National Center for Atmospheric Research Community Climate Model indicate enhanced monsoonal circulation over continents, especially southern Asia, at this time. In central Asia, however, the value precipitation-minusevaporation is reduced so that the modeled net effect of the Holocene climatic optimum in this area is an increase in aridity.

Results of the CLIMAP (Climate: Longrange Investigation, Mapping and Prediction) project studies in the Pacific Ocean (Moore et al., 1980) show that 18,000 years ago the steep portion of the sea-surface temperature gradient in the northwest Pacific was shifted $5^{\circ}$ to the south of its present position. As subtropical sea surface temperatures remained unchanged or even warmed up, the glacial age polar cooling resulted in a larger temperature gradient across the zone of the westerlies, as well as an equatorward shift of ocean circulation patterns (Thompson and Shackleton, 1980). The steeper gradient would be expected to enhance both atmospheric and oceanic circulation.

Indices of modern atmospheric circulation for the northern hemisphere (Wallace and Hobbs, 1977) or for the Northwest Pacific in particular (Oort, 1983) show that in the upper troposphere the most intense winds, reaching $40 \mathrm{~m} \mathrm{~s}^{-1}$, occur between $30^{\circ} \mathrm{N}$ (in winter) and $40^{\circ} \mathrm{N}$, and decrease in intensity to the north. This zone of high winds, the jet stream, lies several degrees south of the main gradient in sea-surface temperature.

Eolian deposition in the North Pacific has been the subject of numerous investigations over the past two decades (Windom, 1975). Ferguson et al. (1970) in the northeast Pacific, and Blank et al. (1985) in the northwest Pacific have demonstrated that aerosol mineralogy matches that of surface sediments of the sea floor. Leinen and co-workers (Leinen and Heath, 1981; Leinen et al., 1986) have shown that concentration patterns of quartz, an unequivocally eolian mineral in pelagic sediments, in North Pacific surface sediments mimics present atmospheric circulation patterns. Pleistocene records of eolian deposition have been studied by Janecek (1983), Pisias and Leinen (1984), Janecek and Rea (1985), and Morley et al. (1987) all of whom were able to document the presence of Milankovitch orbital periodicities in the eolian materials. Longerterm records of eolian deposition in the North Pacific have been provided by Rea and Janecek (1982), Janecek and Rea (1983), Janecek (1985), Leinin (1985), and Rea et al. (1985). Together, these reports document the history of eolian deposition since the Late Cretaceous and indicate important changes in eolian processes during the earliest Eocene, the Miocene, especially later portions, and the mid-Pliocene when an order of magnitude increase in the dust flux from continents to the North Pacific occurred. The combined efforts of all these authors suggest that eolian dust composes essentially the entire mineral fraction of the North Pacific pelagic sediments they studied, which include two cores lying along the transect that is the subject of this paper.

In this study we concentrate on the record of the past 30,000 years. We hope to be able to document: the changing aridity patterns of the integrated eolian source region in China from this distal perspective, based on dust flux data; and changes in the latitudinal position of the intense portion of the westerlies, based on the eolian grainsize data. The resulting information will be suitable for comparison with landbased records of late Pleistocene and Holocene climate of east-central Asia, and with computer-based hindcasts of prevailing conditions there. 


\section{Sediments, stratigraphy, and analyses}

Samples were obtained from six cores which together form a longitudinal transect across the prevailing westerlies near $160^{\circ} \mathrm{E}$, between about $28.5^{\circ}$ and $46.5^{\circ} \mathrm{N}$ (Fig.1, Table I). The transect lies approximately $2500 \mathrm{~km}$ downwind from mainland China and $3500 \mathrm{~km}$ from the important dust source regions (Zhang, 1983; Kukla, 1987). Most samples are dominated by the non-biogenic, mineral component and so are diatom silty clays or radiolarian-bearing diatom silty clays. We deliberately chose cores that had been studied by the CLIMAP project and adopted their stratigraphy (Shackleton, 1977; Moore et al., 1980). When possible, cores were sampled at a 6000 -year interval from 0 to 30,000 years, spacing being determined by the location of the 18,000 year horizon and the assumption of linear sedimentation rates. One core, RC-14-105, was sampled more closely. This sampling strategy allows construction of north-south profiles, time slices, of eolian indicators at 6000 -year intervals.

The mineral component of each sample was isolated by a series of extractions to remove calcium carbonate, various oxides and hydroxides, and opal; details of these procedures are given by Rea and Janecek (1981). The extraction procedure has a precision of about $\pm 5 \%$. Because of their location immediately downwind from the West Pacific island arcs there is a small amount of volcanic glass (ash) in most

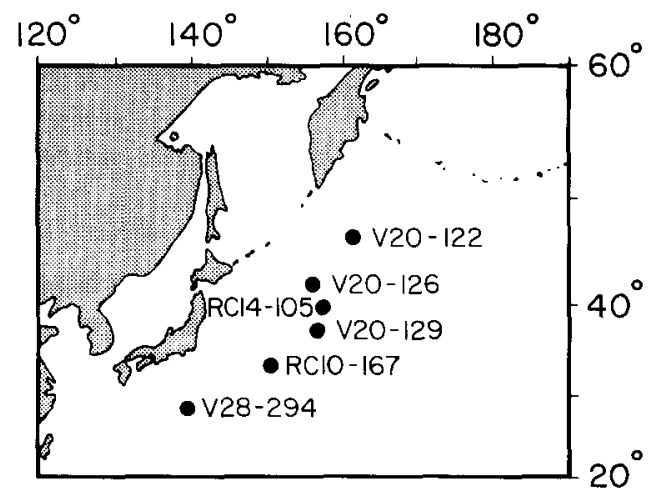

Fig.1. Index map of the North Pacific Ocean showing core locations.
TABLE I

Locations of cores studied

\begin{tabular}{lll}
\hline Core & Latitude & Longitude \\
\hline V-20-122 & $46^{\circ} 34^{\prime} \mathrm{N}$ & $161^{\circ} 41^{\prime} \mathrm{E}$ \\
V-20-126 & $42^{\circ} 09^{\prime} \mathrm{N}$ & $155^{\circ} 52^{\prime} \mathrm{E}$ \\
RC-14-105 & $39^{\circ} 41^{\prime} \mathrm{N}$ & $157^{\circ} 33^{\prime} \mathrm{E}$ \\
V-20-129 & $37^{\circ} 41^{\prime} \mathrm{N}$ & $156^{\circ} 35^{\prime} \mathrm{E}$ \\
RC-10-167 & $33^{\circ} 24^{\prime} \mathrm{N}$ & $150^{\circ} 23^{\prime} \mathrm{E}$ \\
V-28-294 & $28^{\circ} 26^{\prime} \mathrm{N}$ & $139^{\circ} 58^{\prime} \mathrm{E}$ \\
\hline
\end{tabular}

of the samples which can not be removed completely by the extraction procedures. Smear slides of the extracted grains show that glass rarely exceeds 10 or $15 \%$ of the sample, but this ash is included in the calculation of weight percents which, therefore, are slightly higher than the true, continentally derived mineral percentages (Table II). Data from one sample that was predominantly ash, V-20-126, $115 \mathrm{~cm}$, were not used in any interpretations.

The parameter required for proper quantitative interpretation of paleoprocesses is not the weight percent of any one sedimentary constituent, which varies in response to the input of every component to the sediment, but the mass accumulation rate (MAR), measured in $\mathrm{g} \mathrm{cm}^{-2} 10^{-3} \mathrm{yr}^{-1}$, of the individual component in question. The flux values given here are the product of the amount of mineral dust in wt.\%, the linear sedimentation rate (LSR) in $\mathrm{cm}^{1-3}$ $\mathrm{yr}^{-1}$, and the dry bulk density (DBD) of the sediment in $\mathrm{g} \mathrm{cm}^{-3}$. Linear sedimentation rates were based on the determination of the 18,000 year horizon made by the CLIMAP project (Shackleton, 1977; Moore et al., 1980),

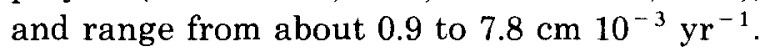
Determination of $\mathrm{DBD}$ values from dried samples depends on measuring the dried salt in a sample, assuming a paleosalinity, and backcalculating the original water content. We estimate these values (Table II) to be within $\pm 25 \%$ of the real ones; this aspect of the analyses of such samples is often the step that limits the resulting accuracy. Nevertheless, DBD values, average about $0.2-0.3 \mathrm{~g} \mathrm{~cm}^{-3}$, approximately the value measured for fresh 
TABLE II

Eolian data from Northwest Pacific cores. DBD is dry bulk density, LSR is linear sedimentation rate, MAR is mass accumulation rate

\begin{tabular}{|c|c|c|c|c|c|c|}
\hline $\begin{array}{l}\text { Depth } \\
(\mathrm{cm})\end{array}$ & $\begin{array}{l}\text { Age } \\
\left(10^{3} \mathrm{yr}\right)\end{array}$ & $\begin{array}{l}\mathrm{DBD} \\
\left(\mathrm{g} \mathrm{cm}^{-3}\right)\end{array}$ & $\begin{array}{l}\text { LSR } \\
\left(\mathrm{cm} 10^{-3} \mathrm{yr}^{-1}\right)\end{array}$ & $\begin{array}{l}\text { Dust } \\
\text { (wt\%) }\end{array}$ & $\begin{array}{l}\text { Dust MAR } \\
\left(\mathrm{mg} \mathrm{cm}-210^{-3} \mathrm{yr}^{-1}\right)\end{array}$ & $\begin{array}{l}\text { Dust size } \\
\left(\phi_{50}\right)\end{array}$ \\
\hline \multicolumn{7}{|c|}{$V-20-122$} \\
\hline 10.0 & 2.24 & 0.18 & 4.47 & 59.8 & 486 & 8.33 \\
\hline 27.0 & 6.04 & 0.23 & 4.47 & 73.5 & 769 & 8.47 \\
\hline 49.0 & 10.96 & 0.26 & 4.47 & 58.4 & 671 & 8.86 \\
\hline 80.0 & 17.90 & 0.19 & 4.47 & 75.8 & 651 & 8.36 \\
\hline 107.0 & 23.94 & 0.27 & 4.47 & 75.5 & 911 & 8.47 \\
\hline 133.5 & 29.87 & 0.36 & 4.47 & 75.3 & 1209 & 7.93 \\
\hline \multicolumn{7}{|c|}{$V-20-126$} \\
\hline 18.5 & 2.99 & 0.16 & 6.19 & 55.9 & 557 & 8.38 \\
\hline 41.5 & 6.70 & 0.23 & 6.19 & 71.0 & 1028 & 8.11 \\
\hline 68.8 & 11.11 & 0.13 & 6.19 & 76.1 & 627 & 8.82 \\
\hline 115.0 & 18.58 & 0.28 & 6.19 & 78.8 & 1346 & nd \\
\hline 149.0 & 24.07 & 0.21 & 6.19 & 74.6 & 947 & 8.48 \\
\hline 184.0 & 29.73 & 0.16 & 6.19 & 72.2 & 720 & 8.26 \\
\hline \multicolumn{7}{|c|}{$R C-14-105$} \\
\hline 1.0 & 0.16 & 0.19 & 6.10 & 57.7 & 658 & 8.49 \\
\hline 11.0 & 1.80 & 0.26 & 6.10 & 59.7 & 947 & 8.30 \\
\hline 20.0 & 3.28 & 0.20 & 6.10 & 53.2 & 643 & 8.39 \\
\hline 34.5 & 5.66 & 0.36 & 6.10 & 75.6 & 1678 & 7.99 \\
\hline 45.0 & 7.38 & 0.26 & 6.10 & 64.3 & 1001 & 8.52 \\
\hline 59.0 & 9.67 & 0.22 & 6.10 & 64.4 & 880 & 8.39 \\
\hline 65.5 & 10.74 & 0.29 & 6.10 & 63.5 & 1108 & 8.06 \\
\hline 85.0 & 13.93 & 0.20 & 6.10 & 69.3 & 845 & 7.70 \\
\hline 97.5 & 15.98 & 0.22 & 6.10 & 66.1 & 879 & 8.48 \\
\hline 111.0 & 18.20 & 0.19 & 6.10 & 64.3 & 725 & 8.45 \\
\hline 135.5 & 22.25 & 0.19 & 6.00 & 66.5 & 746 & 8.37 \\
\hline 143.0 & 23.50 & 0.20 & 6.00 & 61.6 & 739 & 8.20 \\
\hline 147.0 & 24.17 & 0.22 & 6.00 & 63.8 & 846 & 8.26 \\
\hline 153.0 & 25.17 & 0.18 & 6.00 & 63.4 & 692 & 8.34 \\
\hline 158.5 & 26.08 & 0.19 & 6.00 & 62.7 & 722 & 8.25 \\
\hline 168.5 & 27.75 & 0.22 & 6.00 & 66.7 & 896 & 8.37 \\
\hline \multicolumn{7}{|c|}{$V-20-129$} \\
\hline 11.0 & 1.41 & 0.20 & 7.78 & 64.9 & 999 & 8.23 \\
\hline 45.0 & 5.78 & 0.31 & 7.78 & 66.4 & 1596 & 8.07 \\
\hline 85.0 & 10.93 & 0.27 & 7.78 & 62.4 & 1301 & 8.23 \\
\hline 139.5 & 17.93 & 0.21 & 7.78 & 65.9 & 1066 & 8.40 \\
\hline 185.0 & 23.78 & 0.29 & 7.78 & 69.6 & 1591 & 8.33 \\
\hline 231.0 & 29.35 & 0.27 & 7.78 & 68.1 & 1431 & 8.63 \\
\hline \multicolumn{7}{|c|}{$R C-10-167$} \\
\hline 5.5 & 2.25 & 0.20 & 2.44 & 85.1 & 411 & 8.26 \\
\hline 10.5 & 4.30 & 0.21 & 2.44 & 86.9 & 452 & 8.20 \\
\hline \multicolumn{7}{|c|}{$V-28-294$} \\
\hline 1.0 & 1.16 & 0.24 & 0.86 & 26.8 & 55 & 8.19 \\
\hline 16.0 & 18.60 & 0.55 & 0.86 & 32.5 & 211 & 8.10 \\
\hline
\end{tabular}


samples of the same composition. Resulting values for MAR are accurate to about $\pm 25 \%$; our interpretations are based on a several-fold variation in MAR.

The size of the eolian grains was measured by an electronic particle size analyzer. Results are reported as median grainsize of the total eolian component, $\phi_{50}$ of Folk (1974); repeated measurements indicate a precision of $\pm 0.05 \phi$ for these values (Table II). [ $\phi$ units are the sedimentologist's measure of grainsize, $\phi=-\log (2) \mathrm{Dmm}$, the negative $\log$ to the base 2 of the grain diameter in millimeters. Thus: $10 \phi=1 \mu \mathrm{m}, 9 \phi=2 \mu \mathrm{m}, 8 \phi=4 \mu \mathrm{m}$, etc.]

\section{The eolian record}

The mass flux of dust to the sea floor in the cores along the westerlies transect ranges from 500 to almost $1700 \mathrm{mg} \mathrm{cm}^{-2} 10^{-3} \mathrm{yr}^{-1}$. These values are similar to those measured for eolian deposition throughout the Plio-Pleistocene at nearby sites in the northwest Pacific by Janecek (1985). Four of the cores provide records that span the past 30,000 years (Fig.2). All of them show moderately low dust inputs at present and at 18,000 years ago, the time of the last glacial maximum. Maxima in dust flux occurred 6000 years ago and about 24,000 years ago although the earlier interval has a somewhat lower flux. When arranged in time slices along the transect (Fig.3), the data show that

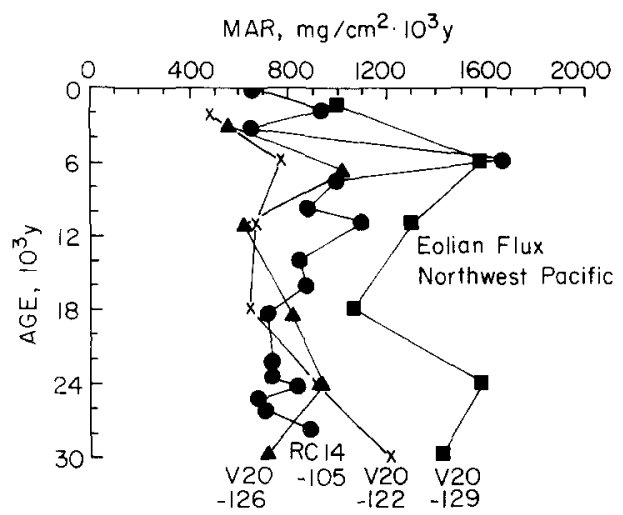

Fig.2. Downcore record of eolian dust flux to the North Pacific. Flux maxima occur at about 6000 and perhaps 24,000 years ago.

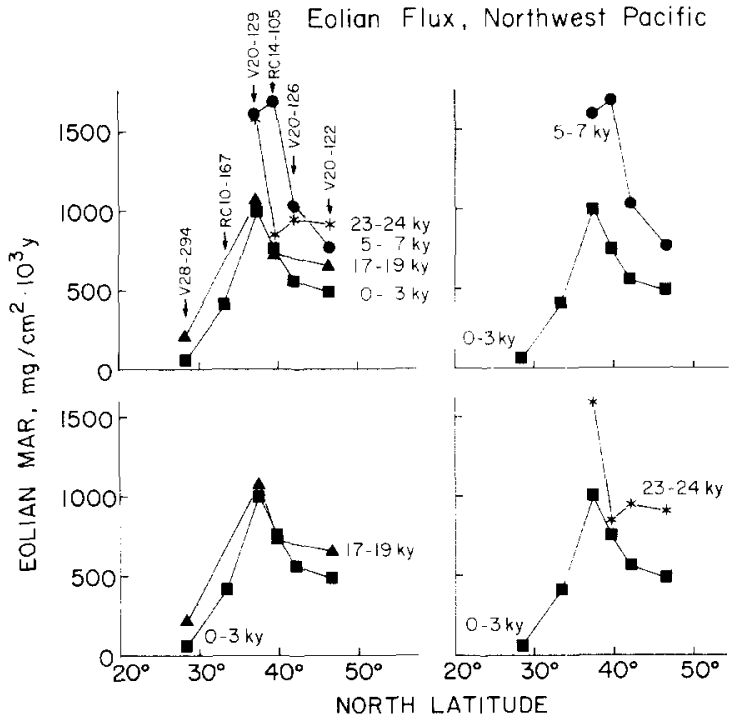

Fig.3. Dust flux along the latitudinal profile for different time slices. Throughout the record, the greatest flux is always at about $38-40^{\circ} \mathrm{N}$

the greatest eolian flux has always been in the vicinity of $38-40^{\circ} \mathrm{N}$. Flux values are nearly doubled during the 6000 year-old maximum but the latitudinal position of the peak does not change.

Eolian grains from the northwest Pacific are commonly $8.2-8.5 \phi(3.40-2.76 \mu \mathrm{m})$ in diameter (Fig.4), slightly coarser than those sampled about $2000 \mathrm{~km}$ to the east which are $8.5-8.7 \phi$ $(2.76-2.40 \mu \mathrm{m})$ in diameter (core KK75-02, Janecek and Rea, 1985). Downcore plots of the

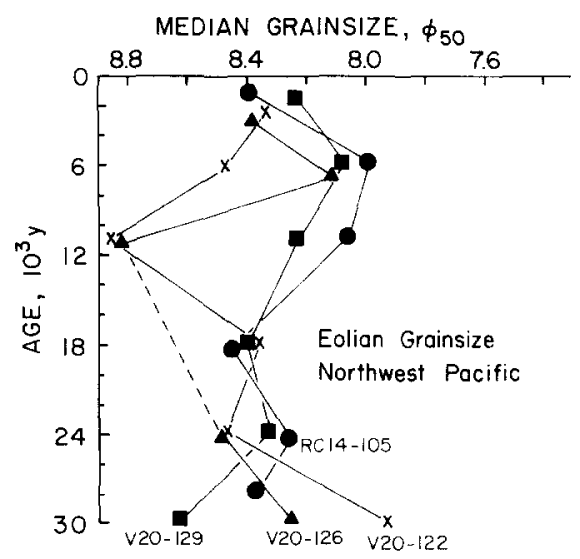

Fig.4. Downcore record of dust grainsize. 


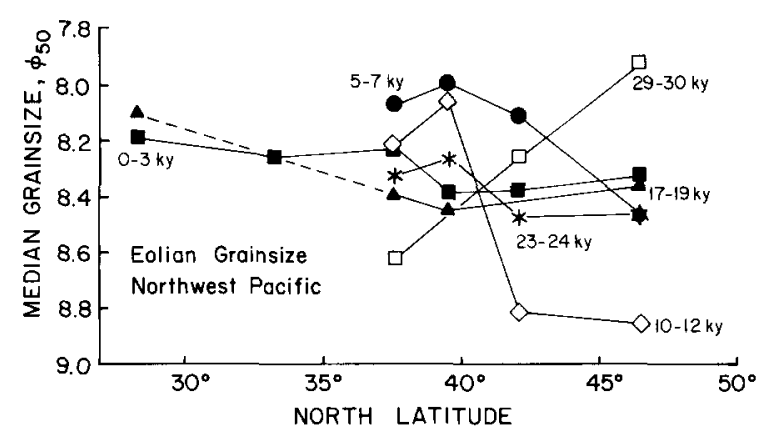

Fig.5. Eolian grainsize along the latitudinal profile for different time slices. Largest gradients are at 11,000 and 6000 years ago.

eolian grainsize show that the range of grainsizes along the transect is low at present and from 18,000 to 24,000 years ago. The maximum sizes occurred 6000 years ago, and the greatest range in size occurred at 11,000 years ago (Fig.4).

The time-slice diagram of eolian grainsize (Fig.5) shows how this parameter has changed during the past 30,000 years. In the surface samples the size of the eolian grains reflects the present upper tropospheric winds, being coarser south of $39^{\circ} \mathrm{N}$. The 18,000 year curve is similar to the present. Because we are missing the 18,000 year old sample from RC10-167 at $33.4^{\circ} \mathrm{N}$, we can only state that any significant size gradient must lie south of $37.7^{\circ} \mathrm{N}$ and north of $28.4^{\circ} \mathrm{N}$ at 18,000 years ago. The 11,000 year size record shows a significant gradient from coarse grains at $39.7^{\circ} \mathrm{N}$ to fine grains at $42.2^{\circ} \mathrm{N}$. At 6000 years ago the northerly reduction in grainsize decreased to $60 \%$ of the 11,000 yearold value and the entire gradient shifted north 3 or $4^{\circ}$ of latitude. Older sediments show little change in grainsize between 18,000 and 24,000 years ago. The $28,000-30,000$ year old samples coarsen significantly to the north, a noticeably different pattern than that observed for the younger time slices.

\section{Interpretation and discussion}

\section{Asian aridity}

The flux of dust from the Asian continent to the northwestern Pacific was at a maximum about 6000 years ago. Flux values at that time reached $1680 \mathrm{mg} \mathrm{cm}^{-2} 10^{-3} \mathrm{yr}^{-1}$, roughly twice the overall average values (Fig.2). This observation is in general agreement with the work of Street-Perrott (1986) showing that midlatitude Holocene lake levels were at their lowest about 7000 to 6000 years ago, with field work in Tibet indicating the same conclusion (Wang and Fan, 1987), and provides additional support for the model result indicating that values of precipitation-minus-evaporation in the region north of the Himalayas were less than today's during the time span 9000-6000 years ago (Kutzbach and Guetter, 1986). Enhanced continental humidity at 18,000 years ago and the present is indicated by reduced dust flux values at those times.

The youngest unit of the classic Chinese Plio-Pleistocene loess sequence is the Milan loess which has been dated by thermoluminescence techniques and may range in age from about 20,000 to 70,000 years (Kukla, 1987). If the proximal land and distal marine records of this eolian activity are correlative, then the information presented here is consistent with a youngest age of about 20,000 years for the Milan loess.

Regardless of the variation in dust supply, the latitudinal position of the flux maxima remained unchanged at $38^{\circ}$ to $40^{\circ} \mathrm{N}$. This is almost the exact latitude of the dust storm region of China which extends from Beijing westward through $40^{\circ}$ of longitude and which has been observed for 3000 years (Zhang, 1983, 1984). The marine record (Fig.3) suggests that dust from Asian source regions has been transported easterly along roughly the same latitude for the past 30,000 years, through times of major shifts in global climate.

\section{Wind intensity}

The eolian grainsize data define the northern margin of the zone of intense westerlies, but, unfortunately, not its southern extent (Fig.5). Samples representing the 30,000-year old time slice might not be predominantly eolian, but rather the observed northward coarsening 
may reflect enhanced hemipelagic deposition caused by greater fluvial input to the Okhotskwestern Bering region then. The 24,000- and 18,000-year time slices are not as well defined as the others and seem similar to the present; any large gradient in wind intensity lay south of $37.7^{\circ} \mathrm{N}$ at those times. During deglaciation the northern margin of the intense westerlies shifted north to $41^{\circ} \mathrm{N}$ at 11,000 years ago and continued to 44 or $45^{\circ} \mathrm{N}$ by 6000 years ago, a poleward migration rate of about $80 \mathrm{~km} 10^{-3}$ $\mathrm{yr}^{-1}$. The inferred reduction in wind intensity from south to north across this zone is quite pronounced at 11,000 years ago, perhaps twice that of today (based on the intensity-grainsize relationship of Janecek and Rea, 1985), with that at 6000 years ago being almost $50 \%$ larger (ibid.). Since 6000 years ago this northern margin of the strong westerlies has migrated back towards the equator and become much less pronounced.

This picture of retreat of the northern margin of the intense westerlies to its most poleward extent at 6000 years ago is consistent with our understanding of a mid-Holocene climatic optimum followed by a more recent cooling and with other information gleaned from North Pacific sediments (Morley et al., 1986). The change in presumed wind intensity across this boundary, however, did not reach a minimum at 6000 years ago, but rather has decreased continuously throughout the Holocene. Changes in latitude and intensity of zonal winds during times of great climatic change do not, therefore, seem to go hand-inhand.

\section{Summary}

The 30,000-year record of eolian deposition in the northwest Pacific Ocean presents an integrated picture of both continental aridity and the zonal westerly winds during that time period. These data emphasize the Holocene climatic optimum as the time of greatest postglacial aridity in China and the time when the intense core of the zonal westerlies reached its northernmost latitudinal extent. Throughout the period studied, a time of great climatic change on the Asian continent, transport from the eolian source region appears to have remained at the same latitude, although aridity in the source area changed.

The eolian record is an example of one type of data that can be used to verify computer models of past climates. In this instance the model results of Kutzbach and Guetter (1986), indicating enhanced aridity in central and western China during the mid-Holocene, even though monsoonal circulation may be enhanced then, appear valid.

\section{Acknowledgments}

Samples for this project were provided by the Core Laboratory of Lamont-Doherty Geological Observatory. This work was supported by the Climate Dynamics Program, National Science Foundation, grant ATM-8116300.

\section{References}

Blank, M., Leinen, M. and Prospero, J. M., 1985. Major Asian aeolian inputs indicated by the mineralogy of aerosols and sediments in the western North Pacific. Nature, 314: 84-86.

Ferguson, W. S., Griffin, J. J., and Goldberg, E. D., 1970. Atmospheric dusts from the North Pacific -- A short note on long range eolian transport. J. Geophys. Res., 75: 1137-1139.

Folk, R. L., 1974. Petrology of Sedimentary Rocks. Hempthill, Austin, Tex., 182 pp.

Janecek, T. R., 1983. The History of Eolian Sedimentation and Atmospheric Circulation During the Late Cenozoic. Thesis. Univ. Michigan, Ann Arbor, Mich., $176 \mathrm{pp}$. (unpublished).

Janecek, T. R., 1985. Eolian sedimentation in the northwest Pacific Ocean: A preliminary examination of the data from Deep Sea Drilling Project Sites 576 and 578. In: G. R. Heath, L. H. Burckle, et al., Initial Reports of the Deep Sea Drilling Project, 86. U.S. Government Printing Office, Washington, D.C., pp. 589603

Janecek, T. R. and Rea, D. K., 1983. Eolian deposition in the northeast Pacific Ocean: Cenozoic history of atmospheric circulation. Geol. Soc. Am. Bull., 94: 730-738.

Janecek, T. R. and Rea, D. K., 1985. Quaternary fluctuations in the Northern Hemisphere tradewinds and westerlies. Quat. Res., 24: 150-163.

Kukla, G., 1987. Loess stratigraphy in central China. Quat. Sci. Rev., 6: 191-219.

Kutzbach, J. E. and Guetter, P. J., 1986. The influence of changing orbital parameters and surface boundary 
conditions on climate simulations for the past 18,000 years. J. Atmos. Sci., 43: 1726-1759.

Leinen, M., 1985. Quartz content of northwest Pacific Hole 576A and implications for Cenozoic eolian transport. In: G. R. Heath, L. H. Burckle et al., Initial Reports of the Deep Sea Drilling Project, 86. U.S. Government Printing Office, Washington, D.C., pp.581-588.

Leinen, M. and Heath, G. R., 1981. Sedimentary indicators of atmospheric circulation in the Northern Hemisphere during the Cenozoic. Palaeogeogr., Palaeoclimatol., Palaeoecol., 36: 1-21.

Leinen, M., Cwienk, D., Heath, G. R., Biscaye, P. E., Kolla, V. Thiede, J. and Dauphin, J. P., 1986. Distribution of biogenic silica and quartz in Recent deep-sea sediments. Geology, 14: 199-203.

Moore, T. C., Jr., Burckle, L. H., Geitzenauer, K., Luz, B., Molina-Cruz, A., Robertson, J. H., Sachs, H., Sancetta C., Thiede, J., Thompson, P. and Wenkham, C., 1980. The reconstruction of sea surface temperatures in the Pacific Ocean of 18,000 B.P. Mar. Micropaleontol., 5: 215-247.

Morley, J. J., Heusser, L. E. and Sarro, T., 1986. Latest Pleistocene and Holocene paleoenvironment of Japan and its marginal sea. Palaeogeogr., Palaeoclimatol., Palaeoecol., 53: 349-358.

Morley, J. J., Pisias, N. G. and Leinen, M., 1987. Late Pleistocene time series of atmospheric and oceanic variables recorded in sediments from the subarctic Pacific. Paleoceanography, 2: 49-62.

Oort, A. H., 1983. Global Atmosphere Circulation Statistics, 1958-1973. NOAA Prof. Pap. 14, 180 pp.

Pisias, N. G. and Leinen, M., 1984. Milankovitch forcing of the oceanic system: Evidence from the northwest Pacific. In: A. Berger, J. Imbrie, J. Hays, G. Kukla and B. Saltzman (Editors), Milankovitch and Climate, Understanding the Response to Orbital Forcing, Part 1. Reidel, Dordrecht, pp. 307-330.
Prell, W. L. and Kutzbach, J. E., 1987. Monsoon variability over the past 150,000 years. J. Geophys. Res., 92: $8411-8425$.

Rea, D. K. and Janecek, T. R., 1981. Mass accumulation rates of the non-authigenic inorganic crystalline (eolian) component of deep sea sediments from the Mid-Pacific Mountains, Deep Sea Drilling Project Site 463. In: J. Thiede, T. L. Vallier et al., Initial Reports of the Deep Sea Drilling Project, 62. U.S. Government Printing Office, Washington, D.C., pp. 653-659.

Rea, D. K. and Janecek, T. R., 1982. Late Cenozoic changes in atmospheric circulation deduced from North Pacific eolian sediments. Mar. Geol., 49: 149-167.

Rea, D. K., Leinen, M. and Janecek, T. R., 1985. Geologic approach to the long-term history of atmospheric circulation. Science, 227: 721-725.

Shackleton, N. J., 1977. The oxygen isotope stratigraphic record of the late Pleistocene. Philos. Trans. R. Soc. Lond., 280B: 169-182.

Street-Perrott, F. A., 1986. Proc. NASA Workshop on Climate-Vegetation Interactions, Goddard Space Flight Center, Greenbelt, Md.

Thompson, P. R. and Shackleton, N. J., 1980. North Pacific paleoceanography: late Quaternary coiling variations of planktonic foraminifer Neogloboquadrina pachyderma. Nature, 287: 829-833.

Wallace, J. M. and Hobbs, P. V., 1977. Atmospheric Science. Academic Press, New York, N.Y., 467 pp.

Wang, F.-B. and Fan, C. Y., 1987. Climatic changes in the Qinghai-Xizang (Tibetan) region of China during the Holocene. Quat. Res., 28: 50-60.

Windom, H. L., 1975. Eolian contributions to marine sediments. J. Sediment. Petrol., 45: 520 529.

Zhang, D., 1983. Analysis of dust rain in the historic times of China. Keuxe Tongbao, 28: 361-366.

Zhang, D., 1984. Synoptic-climatic studies of dust fall in China since historic times. Sci. Sin., 27: 825-836. 